\title{
Principals Shaping School Culture for School Effectiveness in South Africa
}

\author{
Keshni Bipath and Eles Moyo \\ University of Pretoria, Pretoria, South Africa 0002
}

KEYWORDS Principals’ Leadership Practices. School Effectiveness and Improvement. School Culture

\begin{abstract}
This paper explores effective schools with an effective school culture. The researchers worked from the assumption that a positive school culture is essential for school effectiveness and that principals are in a position to exert a greater influence on the school culture than any other member of the school community. In democratic South Africa, black parents who needed good education for their children could not always find it in schools that catered for blacks only. They therefore sent their children to effective suburban schools, which resulted in a large influx of learners from outer areas. Schein's 3-level theory of culture and Zhang's four constructs of culture were used as theoretical lenses for this research. This qualitative study, which employed the photo-voice method, narrative interviews and structured observations, revealed that effective principals adapted to the changing school population and prepared learners, teachers and communities for success against all odds.
\end{abstract}

\section{INTRODUCTION}

Principals as leaders play a central role in a school situation. They give direction to all the school programmes and thereby influence both the school culture and teacher performance (Engels et al. 2008: 160). Leo and Wickenberg (2013: 407) describe principals as “change agents” and “culture builders”. Schein (2010: 22) contends that "culture begins with leadership" and that "culture and leadership are two sides of the same coin", in that leaders create culture when they create groups and organisations. Principals do not only create the school culture, they also manage it. Sometimes they are even expected to change it or to break it down. The principal as the leading professional therefore holds, articulates and communicates accepted professional and social values (DoE 2014: 8).

Spaull (2012: 4) notes that school culture in effective schools is characterised by strong accountability, good management, a culture of learning, discipline and order, adequate learning, teaching and support material, adequate teacher content knowledge, a completed curriculum, adequate learner performance and a low rate of learners dropping out. Effective school principals view proper time management and organising the school day for effective education as crucial in creating organisational containment and establishing expectations around good quality teaching and learning in the school.

According to the DoE (2014: 7), the culture in effective schools is underpinned by the dem- ocratic practices of the principal as summarised in the various policy documents of the National Department of Education. Principals have the primary responsibility for the creation of a safe, nurturing and supportive learning environment, which enables effective teaching and learning to take place. The principal is expected to create an atmosphere that inspires high levels of achievement and commitment from all who work in the school, and at the same time to develop an environment that is based on human values (November et al. 2012: 789).

Central to principal's leadership and management of the school are core societal and educational values that underpin everything that happens in a school (DoE 2014: 7). Hoadleya et al. (2009: 378) note that principals in effective schools value social relationships among the teachers and other stakeholders. They contend that, given the nature of the South African school curriculum, these interactions are of great importance in terms of designing and delivering learning programmes (November et al. 2012: 789). According to Negis-Isik and Gursel (2013), parents transferred their children to schools characterised by a positive school culture, harmonious relations between teachers and principals with exceptional leadership qualities.

The researchers in the current study worked from the assumption that a positive school culture is essential for school effectiveness and that principals are in a position to exert a greater influence on the school culture than any other member of the school community. 


\section{Theoretical Framework}

\section{Schein's Three Levels of Culture}

Schein (2010: 23) identifies three levels of culture, namely observable artefacts, espoused values, and basic underlying assumptions. He argues that these levels of culture range from the very concrete open indicators that can be seen and felt, to the deeply rooted, unconscious, basic assumptions that are regarded as the essence of culture. Within these layers one finds various espoused beliefs, values, norms, rules and behaviour that principals use to portray their schools' culture to members of the school community.

\section{Observable Artefacts as a Level of School Culture}

Schein (2010: 23) describes the observable artefacts as those things one would see, hear or feel when one encounters a new group or a new environment. The artefacts manifest themselves in the visible world and include the physical environment in which a school functions, its products and the behaviour of members of the school community (Nordengren 2013: 6).

\section{Espoused Values and Beliefs as a Level in School Culture}

The espoused values are advocated by the leadership and management (Tharp 2009: 2). They determine how the leader would deal with a new task, issue or problem, and once the solution has worked, it is transformed into a value. According to Peterson and Deal (2011: 14), values are standards set for what is considered 'good', what quality means, and what defines excellence. Thus values are often open and asserted in a school to the extent that they become compatible with the underlying assumptions, as they assist to develop a sense of identity and identify the core mission of a school (Nordengren 2013: 7).

\section{Basic Underlying Assumptions as a Level in School Culture}

According to Nordengren (2013: 7), the basic underlying assumptions are solutions to problems that have become so accepted by the school community as "the way things are done here", that all other alternatives may appear unavailable. These basic underlying assumptions of the principal and teachers are their unconsciously held and learned responses, which may include concerns about the intellectual abilities and critical thinking of the learners, as well as issues of inclusiveness (Van Deventer and Kruger 2011: 20).

\section{School Culture Based on Zhang's Conceptual Framework}

Zhang (2008: 6) proposes four constructs of school culture, namely environmental culture, the culture of rules and regulations, etiquette culture, and spiritual culture. He concludes that these models of school culture are needed to understand how well a school can perform in the various aspects of its life, and warns that culture building cannot be rushed. It needs time, patience, space and experience. Guthrie and Schuermann (2011: 21) argue that school culture serves as a framework for the way members of the school community "act, interact, think, and feel”, particularly the nature of interactions; the manner in which discussions between individuals are held; the physical appearance of a school and the manner in which it is presented; social standards; values; expectations, and the attitude that the members of the school community hold and act upon.

\section{Aims and Objectives}

In this study, the researchers investigated the link between the theories of Schein and Zhang. The paper examines the practices of principals in shaping a culture conducive to school effectiveness despite the low socio-economic background of the learners and the lack or shortage of teaching and learning resources. The researchers conclude with a model that describes how effective principals shape a culture for school effectiveness in South Africa, as well as in other countries in the world that find themselves attempting to provide high quality education against all odds.

\section{METHODOLOGY}

\section{Participants and Sample Area}

The study used purposive sampling to select two principals of suburban primary schools who had been in a leadership position for more 
than three years. The schools shared the same socio-economic background and both experienced an influx of learners who were not living in the area where the schools are situated. Both schools were suburban, yet the majority of their learners were from the townships. According to the Annual National Assessment (ANA), these two schools scored an average of sixty-five per cent in Literacy and seventy per cent in Numeracy, and hence they were regarded as effective schools. ANA makes provision for standardised national assessments for languages and mathematics in the Intermediate Phase (grades $4-6$ ) and in literacy and numeracy for the Foundation Phase (grades 1 - 3) in South Africa.

\section{Procedure}

In the case study the researchers used the photo-voice method, narrative interviews and structured observations to investigate the phenomenon of school effectiveness. The photovoice method, also known as "reflexive photography" or "photo-elicitation" (Lapenta 2011: 206), chosen because it allowed the participants to be actively involved (Kuratani and Lai 2011: 1). Lapenta (2011: 202) posits that the photovoice method has remained strongly grounded in the clarifications and theoretical views as described by Collier and Collier (1986) when they conducted a study on the method. In the photovoice method, the participating principal takes the photographs and is encouraged to elaborate on their content and meaning during the narrative interview (Lapenta 2011: 206).

The researchers in the current study found that photo-voice as a method was able to meet, almost 'spontaneously', the aims of a qualitatively open-ended interview to describe the contexts and subjects of their research. The principals were requested to take photos of the areas in which they believe they have shaped the culture of their schools since they became principals at that particular school. Cohen et al. (2013: 729) believe that photos are able to "evoke meanings, reflections as well as information and factual data as they are able catch the texture, mood, the atmosphere, the 'feel' of real life and different places”.

\section{Measures}

The research in hand was based on photos that were generated by the participating princi- pals (Pauwels 2011: 52). They were given a week to take10 to 15 photographs of the areas in which they had shaped the school culture. Participant A chose to use his own camera as he was familiar with how it works. Participant B chose to use photos from the school's digital album, since some of the areas involved activities that were non-tangible and could only be visible on the photos taken on the days of the functions. The photos were collected on a memory stick and printed out. They subsequently constituted the basis for an hour-long narrative interview with each participant.

According to Josselson (2010: 871), in narrative interviews the researcher asks questions that require the participant to reflect on how experience is constructed by encouraging the participant to tell stories that give details of their experiences in a rich and specific narration. The narrative interview therefore creates an opportunity to hear the interviewee's voice (Bold 2012: 61 ). During the narrative interview, each principal was requested to arrange the photographs in order of importance and to narrate the story of what was happening on the photograph. This was then followed by structured observation.

Structured observation schedules were used to gather information on the practices of the principals at the two schools. These were pre-designed using Zhang's (2008) conceptual framework on the four constructs of culture that enhance school improvement and development. As a data collection tool, the schedule included both descriptive categories and reflective notes (Creswell 2012a: 166). Observations were made after the narrative interview with the participant and occurred over a period of four days at each research site.

\section{Plan of Analysis}

According to Bold (2012: 121), the purpose of analysis in qualitative research is to "inquire deeply into the meaning of different situations and different people's understandings of the world”. In the current study, data analysis began during the narrative interviews. As the participants started talking about the photographs, they grouped together photos that shared the same idea. This was followed by the breaking down of the sets of data (photographs, transcriptions, observations). 
The data generated from the photographs, narratives and structured observations was organised using the four constructs of school culture as proposed by Zhang (2008), namely environmental culture, the culture of rules and regulations, spiritual culture and etiquette culture. Next, the researchers carefully examined the information gathered to find out which of Schein's embedding mechanisms were used by the principals to shape various aspects of the school culture.

The data obtained from each individual participant's photo-voice, narrative interviews and structured observations was analysed to highlight the various categories derived from their photographs, narrative interviews and the structured observations.

\section{FINDINGS AND DISCUSSION}

Figure 1 shows the relationship between the two theories as extracted from the literature and blends them accordingly. Schein's three levels of culture appear in brackets under the four dimensions of culture as set out by Zhang. Thereafter, the empirical findings are presented for each school and summarised according to Schein's levels of culture and Zhang's four dimensions of culture.

Findings with Regard to Environmental Culture and Schein's Level 1: Artefacts

According to Zhang (2008), the environmental culture of the school consists of two distinct

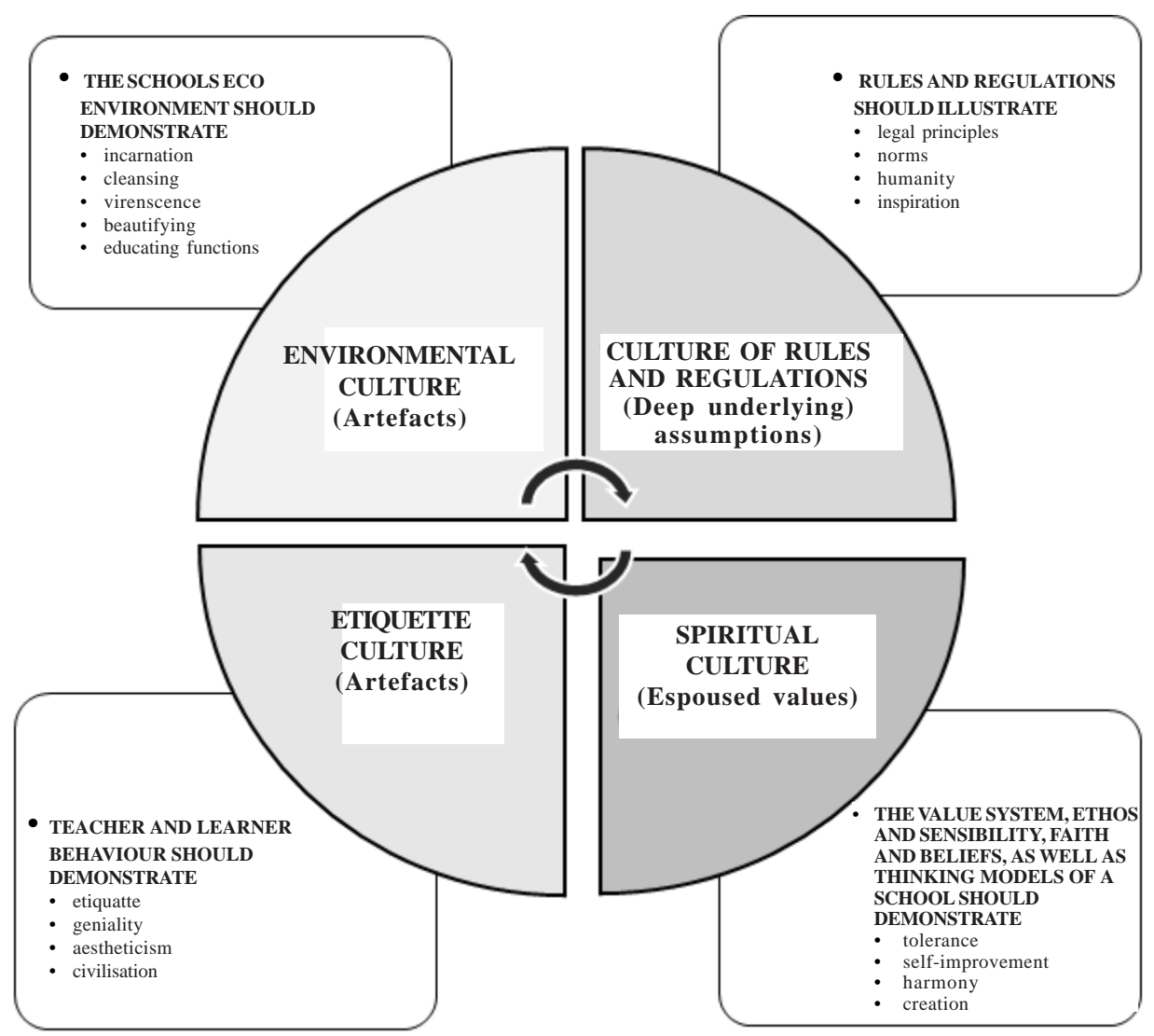

Fig. 1. Graphic representation of Zhang's conceptual framework merged with Schein's three levels of culture

Source: Authors 
aspects: the physical features of the school environment, and the educating function. Van Deventer (2011: 28) and Zengele (2013b: 24) emphasise the need for the school's physical appearance to be good, as it determines the nature and quality of administrative functions and informs visitors whether the school is well or poorly managed. Consequently, the state of a school's physical facilities creates an inviting climate for potential learners (Zengele 2013b: 24). These physical features are visible and could be the reason for parents wanting their children to be in these schools.

\section{Environmental Culture in School A}

School Environment and Physical Features of School A

The principal of School A took a photograph showing the retaining wall (Figure 2) that had recently been built. The retaining wall was built to prevent water running down the sports fields and towards the classrooms during the rainy season.

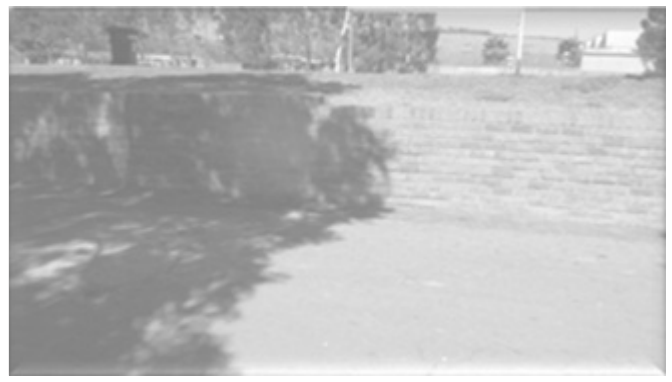

Fig. 2. Retaining wall protecting the classrooms from becoming muddy

Source: Author

Principal A emphasised the need for the school environment to be neat and tidy at all times: The soil ran over the road all the time. So it is important that this was built here for learners' health and the cleanliness of the classrooms.

From Figure 2, it is clear that principal A paid attention to the physical appearance of the school and ensured that the school grounds were well maintained. This was also confirmed during the resaearchers' observations since the school grounds looked beautiful and well maintained and most areas of the school ground had green grass growing. The entrance of the school was beautified with flowers and shrubs. The vegetation that grew in the school yard also confirmed that "virescence", an aspect of Zhang's environmental culture, and other beautifying elements were visible at the school. This indicated that the principal focused on the physical appearance of the school and used it to send a message to the outside world about how well the school was managed. The need for well-maintained school grounds is supported by Zengele (2013b: 24) who emphasises how critical it is for schools to have properly managed school grounds and sufficient play areas for the learners.

Most of Principal A's photographs addressed issues of safety and security. He clearly wanted to create a safe and secure environment where teaching and learning could take place. The principal had a guard house built at the main entrance (Fig. 3). In his interview, he identified the school's geographic position (industrial site) and said that many taxi drivers spent the day loitering outside the school ground. Due to frequent criminal activities and the high unemployment rate in South Africa, the guard house was essential to provide the necessary safety and protection of teachers and learners.

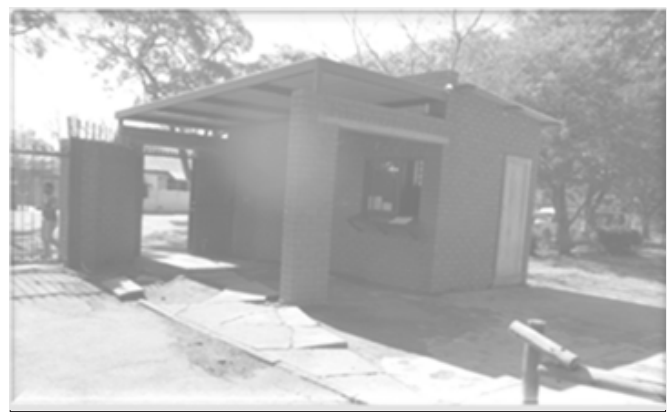

Fig. 3. Guard house

Source: Author

It was also evident during the observation that participant A had created a safe and secure school environment as the school was properly fenced and access to the school was controlled by a security guard. The vehicle and pedestrian gates were always closed, and all visitors who came to the school had to complete a visitors' book before they could access the school premises. Parents who needed to collect their children before the end of the school day had to report at the office and sign to confirm that they 
had collected their child before the end of the school day.

The safety of teachers and learners at schools is a big concern to the Department of Education and the community at large. This has prompted many schools to increase their safety and security measures. The issue of safety at schools is supported by Zengele (2013b: 24) who emphasises the need for schools to make sure that they provide a 'safe haven' for both teachers and learners.

\section{The Educating Function of School A}

The data collected from School A reveals that its principal paid attention to the educating function of the school and was confident that his school was one of the best. He claimed in his interview that "We are effective because we make sure that we hire the best teachers".

Heystek (2012: 14) supports the above and contends that schools know that in order to be competitive, they need to hire the best teachers who will be able to sustain the quality of the education offered by the school. For the school to be able to offer quality education, the principal of School A knew that he had to limit the number of learners in each classroom. Ever since the dawn of democracy in 1994, the school has had to deal with growing numbers of learners who wished to enrol every year. The principal made sure that learners did not over-crowd the classrooms by providing additional mobile classrooms (Fig. 4) to house the ever-growing number of school learners.

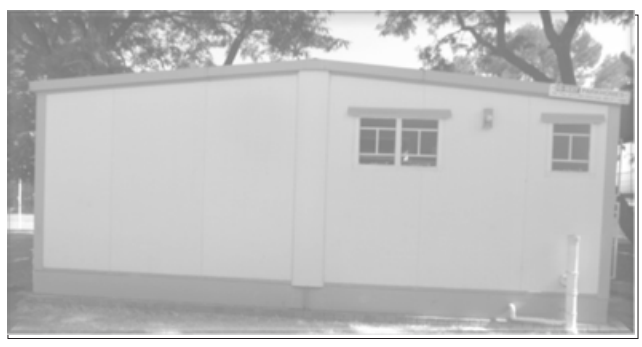

Fig. 4. Mobile classrooms Source: Author

School A also supplemented the number of teachers by employing six extra teachers who were paid by the School Governing Body (SGB) to keep the class sizes small. According to Zen- gele (2013b: 25), schools are advised to avoid overcrowding in the classrooms by making sure that an adequate number of classrooms are provided to avoid the overuse of equipment. The researchers furthermore observed that principal A paid strict attention to enhancing the environmental culture by adhering to the prescribed teaching times. The use of the bell marked the beginning and the end of the school day, and break times. Teachers were time conscious as they were on time at the beginning of the school day and after break. It was also interesting to note that the staffroom was situated opposite the principal's office, which enabled him to keep a watchful eye on the staffroom. The school also had various timetables for duties such as the break duty, assembly duty and extracurricular activities displayed on the noticeboard in the staffroom. The principal had the timetable of each teacher on his noticeboard.

\section{Environmental Culture in School B}

\section{School Environment and Physical Features of School B}

Principal B improved the school environment by building a school hall, which greatly enhanced the physical features of the school (see Fig. 5). The principal was apparently reacting to a crisis as there was an urgent need to build a school hall that could be used to hold assemblies. He commented as follows in his interview: We would plan assembly programmes and if it rains then we would have to cancel. We were not fortunate to have a hall built adjacent to the school. This I felt was a priority as well, to build a hall where children can have assemblies in a shelter.

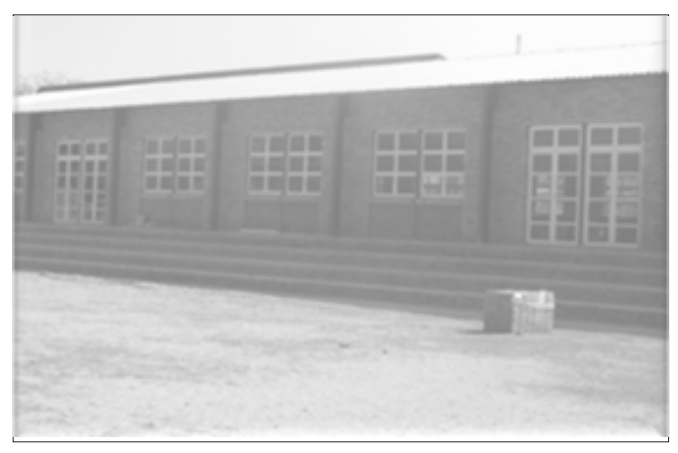

Fig. 5. School hall for assemblies Source: Author 
It was evident from the narrative interview that principal B had worked with limited funds to build the school hall. He had to allocate the available resources cleverly, prioritise projects and work with a strict budget. In the interview he stated:

We are doing it at a very low scale. We are not getting a project manager where the builders buy everything; we are doing it from the school in order to save the cost. We have a builder; we have a person that assists but we buy the things in order to save costs. But that's how we have managed to be at that stage.

Although enhancing the physical features of schools was previously mainly the DoE's responsibility, public schools now have the duty to improve the school's physical features through the SGB. As a way of raising funds, school Bhad a tuckshop as an ongoing fundraising project that was managed by the SGB. The tuckshop sold various food items to learners and teachers. Kruger and Steinmann (2010: 9) point out that in South Africa, schools do not always receive sufficient resources but they are expected to perform efficiently. They also argue that the principal should display sound financial management skills, as those enable him to use the funds appropriately, thereby contributing to school improvement.

\section{The Educating Function of School B}

The educating function of School B is best represented by Figure 6. The school received tablets from the Department of Education. In his interview, the principal quoted the Gauteng MEC of Education, Mr Panyaza Lusufi, who emphasised the need for schools to incorporate different methods of teaching.

What he wants to see in the classroom is not chalk talk anymore and his dream is to see every child using the latest technology.

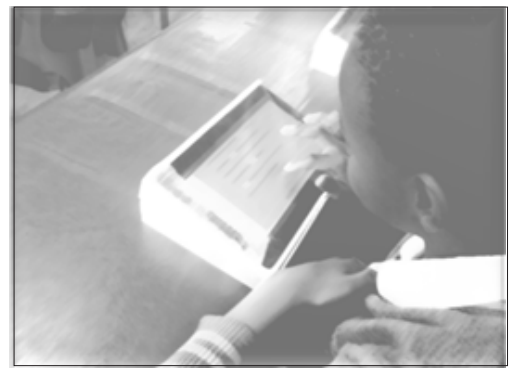

Fig. 6. Use of technology in the classroom Source: Author
The principal of School B revealed that their Maths and English teachers were tasked with extra responsibilities to master the art of teaching via technology. The use of "we" in his narrative interview also indicates that he was a team worker and a role model. He collaborated with his teachers towards realising the MEC's vision of teaching with tablets.

Principal B contributed to the environmental culture by preparing the learners for the future through activities such as the career day organised for the Grade 7s (see Fig. 7). With reduced employment in South Africa and poor career choices made by learners, Principal B showed his visionary nature by getting Grade 7 learners to envision themselves in their careers by dressing up accordingly. He invited professionals from the community to address the Grade $7 \mathrm{~s}$ on career choices.

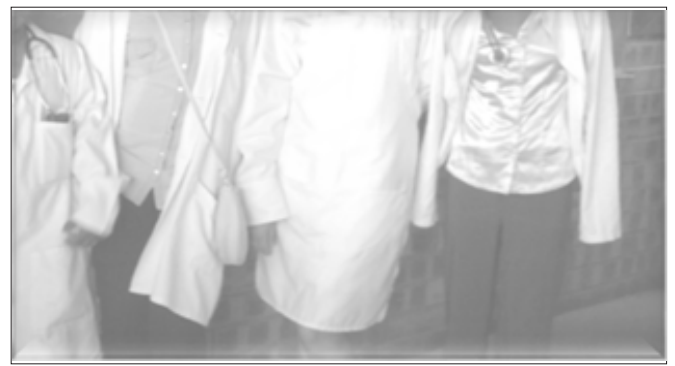

Fig. 7. Career day dress up

Source: Author

Involving professionals from the community as was done by principal B is important. Van Deventer (2010: 260) acknowledges the involvement of the community in school activities as they perpetuate the community's beliefs, values and traditions. Kruger and Steinmann (2010: 10), as well as Turan and Bektas (2013: 162) argue that schools cannot rekindle the culture of teaching and learning on their own; they should rather go into partnership with the community as this helps to improve the quality of the learners' experience in teaching and learning. By getting community members from different professions to address the learners, principal $\mathrm{B}$ empowered his Grade $7 \mathrm{~s}$ and encouraged them to achieve their dreams.

Principal B was actively involved in teaching one of the Grade 7 classes. He also had a time-table file that contained details of all the teachers' workload. This enabled him to monitor 
whether teachers were actually in their classrooms when they needed to be there. The fact that all classrooms were fitted with an intercom helped the principal to communicate with the teachers and learners when there was a need to do so. Principal B clearly showed his awareness of his school and his social responsibility as a leader.

\section{Findings with Regard to the Culture of Rules and Regulations (Level 3: Deep Underlying Assumptions)}

According to Zhang (2008), the culture of rules and regulations involves principles, norms, humanity and inspiration. These rules and regulations are guided by the legal provisions of the particular country, for example it's constitution and all the relevant educational policies. Richard and Catano (2008: 19) remark that a set of rules and regulations should be used to restrict people and should bind, inspire and encourage them to work together. These rules and regulations are evident in the code of conduct, the system of reward and punishment, minutes of meetings, and accountability procedures.

\section{Culture of Rules and Regulations in School A}

In School A, the principal communicated his assumptions by focusing on the culture of rules and regulations. He paid attention to the learners' play areas by expanding the spaces for play and separating the Foundation Phase learners (7 to 9-year-olds) from the Senior Phase learners (10 to 12-year-olds). By separating learners according to their phases, a situation was created to avoid the younger learners being bullied by the older learners during playtime. The separation of learners in School A helped to reduce the number of learners on one play field at a time and made it easy for the teachers to monitor their behaviour.

School A had a working code of conduct that guided all the school's activities. The code of conduct was included in the school diary that was issued to all learners at the beginning of the year. The learners were expected to read and sign the code of conduct with their parents. This code of conduct clearly indicated what was acceptable and what was not acceptable with regard to behaviour, dress, hair styles, the beginning and the end of the school day, etc. The code of conduct also included the school's reward and punishment system.

\section{Culture of Rules and Regulations in School B}

Although the principal of School B had no photographs that reflected the existence of a culture of rules and regulations, it was evident during the researchers' observation that rules and regulations were enforced. It was clear that routines were well established, as a duty list for teachers was displayed in the staffroom. This duty list indicated that two teachers were on duty at a time - in the morning, during break time and at the end of the school day. The teachers were also encouraged to be on duty timeously.

The school made use of learner leaders to assist with the monitoring of learners. The learner leaders wore a reflective vest for visibility over their uniform and had a badge stating that they were learner leaders. These learner leaders patrolled the school grounds before and after school and during break time, making sure that learners were playing in the correct places at all times and were well-disciplined. The school also had a scholar patrol on duty every day to assist fellow learners to cross the street before and after school. Zengele (2013a: 190) supports the use of such a system in schools and remarks that learner leaders are given a sense of importance because they are entrusted with a leadership position. He maintains that this helps them to feel valued as members of the school community and more likely to excel in school activities. When learners know that they are trusted, it becomes easier for them to commit to the school's vision and mission.

Like in School A, School B also had a working code of conduct which was issued to the learners at the beginning of the year. The code of conduct was divided into various categories such as: rules and regulations, learning and teaching, rights and responsibilities of learners, responsibilities of parents, and responsibilities of educators. Learners were regularly reminded of the school rules and regulations during assembly.

Learners in School B were well behaved on the playground. The learners either sat down on the benches provided or on the paved area while they had their lunch. The smaller children played on the play equipment available, while the bigger children played various games. At the end of each period, learners lined up and walked in an orderly manner to their next class. They walked 
on the one side of the corridor to make sure that there was enough space for the learners walking in the opposite direction. A culture of discipline and order was clearly visible.

\section{Findings with Regard to Etiquette Culture}

Zhang describes an etiquette culture as the norms for teacher and student behaviour and remarks that these norms demonstrate etiquette, geniality, aestheticism and civilisation. The etiquette culture of a school is regarded as a general atmosphere of teaching and learning that shows respect for the individual and others. Therefore, an etiquette culture should exhibit orderly procedures, friendliness, and civilisation. Civilisation suggests that learners should conduct themselves in a refined manner, act in a disciplined way, be polite and should uphold the accepted standards of hygiene. Members of the school community are also expected to create relationships on the basis of trust.

\section{Etiquette Culture in School A}

The etiquette culture in School A is demonstrated in Figure 8. The principal of school A created covered parking bays for the vehicles of each individual teacher, thus showing that he cared for his teachers and their possessions.

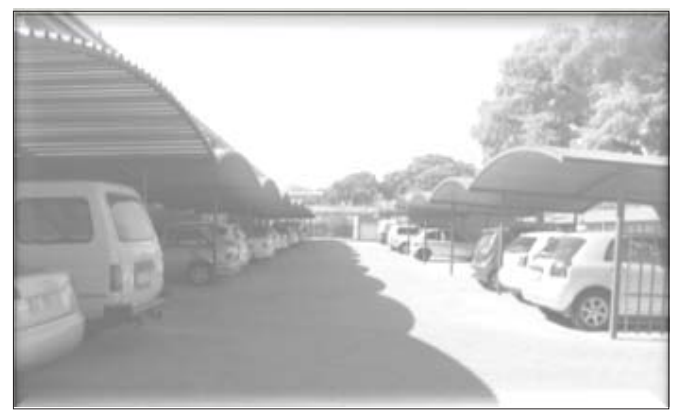

Fig. 8. Covered parking bays Source: Author

Principal A also created a separate entrance for teachers and had it situated where there was no interference from the parents as they came to drop off their children. This gate was also manned by a security guard before and at the end of the school day. According to Zhang (2008) the principal demonstrated geniality in this way.
Zengele (2013b: 24) encourages principals to display a caring attitude towards staff members and states that they should also take an interest in the private lives of their staff members without making them feel uncomfortable. The researchers in the current study observed that by so doing, principal A was able to create a healthy school climate. The teachers felt respected and cared for, and they realised that the principal appreciated their efforts to deliver quality teaching.

\section{Etiquette Culture in School B}

Principal B chose Figure 9 to indicate that he was concerned with the well-being of the learners. The photograph shows learners wrapped in blankets that had been donated by non-governmental organisations (NGOs) from the local community. The principal mentioned that many of the learners in his school came from less fortunate families.

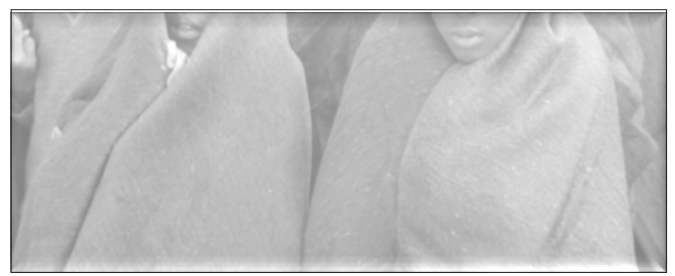

Fig. 9. Learners wrapped in blankets Source: Author

Zengele (2013b: 25) supports the idea of community involvement. He encourages principals to identify and have strong relations with relevant NGOs in their areas so that these organisations may provide services to the teachers and learners, depending on their needs. The principal discussed Figure 9 in conjunction with Figure 10, which shows learners having a meal from the school's feeding scheme.

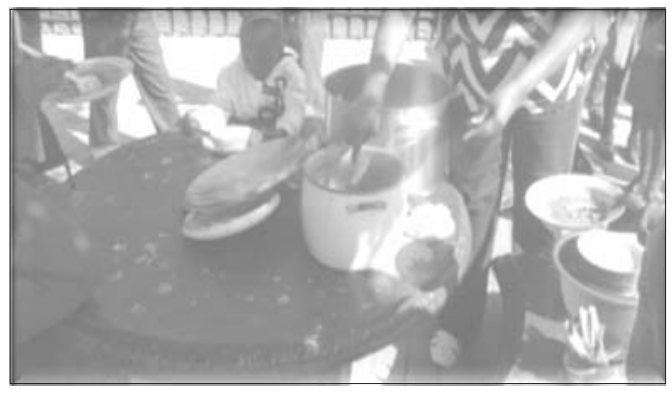

Fig. 10. Feeding scheme

Source: Author 
It was obvious that the principal of school B cared for his learners. He recognised that their critical and impoverished home situation could affect their performance at school and thus paid attention to their basic needs.

Principal B also cared for his teachers, administrative staff and care-takers as he also provided lunch for them bi-annually. Heystek et al. 2012: 15) posits that people constitute the most valuable resource in an organisation. Hence, by paying attention to his human resources, the principal demonstrated that he valued and appreciated them as members of his team. When staff members realise that they are valued and appreciated, they are motivated to succeed in their task (Zengele 2013b: 22) and this will potentially improve relationships.

\section{Findings with Regard to Spiritual Culture}

The spiritual culture of the school outlines the school's personality, life and spiritual quest, and these are evident in its value systems, ethos, faith and beliefs. The school's personality is evident in the school motto, badge, school anthem, school flag, school history, campus stories and anecdotes, and it is demonstrated through assembly themes, newsletters, birthday celebrations, memos, school values and ethos. Zhang believes that the spiritual culture of a school should be evident in the behaviour of all the teachers and learners as they display a sense of tolerance and self-improvement, as well as a harmonious atmosphere. Schools should strive to establish or re-establish their value systems. Guthrie and Schuermann (2011: 11) hold the conviction that a set of core beliefs enables the school community to make sense of life and to live in harmony with themselves and with their peers.

\section{Spiritual Culture in School A}

Although there was no photograph that represented the spiritual culture chosen by principal A, the researchers' observations revealed that the school had its own value system, ethos, faith and beliefs. This was demonstrated by the two assemblies that the school holds weekly, one for the Foundation Phase and one for the Intermediate Phase. Although there were no prescribed assembly themes, the school focused on imparting to the learners messages that had a moral lesson. These messages were presented by the teachers. It was also observed that the school had an anthem that was printed in the learners' diaries and sung during assembly. Having the school anthem in their diaries enabled all learners to learn the lyrics of the song. The researchers also observed that the school celebrated the teachers' and learners' birthdays. Both learners and teachers received a birthday card from the principal during assembly. Monthly newsletters were the visible communication with parents and were seen as essential in building a partnership between parents and teachers and establishing a positive learning culture.

A large painting of the school badge took pride of place on the door at the main entrance to the office area. This showed that the principal valued the badge as one of the school's symbols. The school ethos and values were also displayed in the foyer where all parents and visitors could read them. Each learner received a school diary that contained the National Anthem, the school anthem, and the school's vision and mission. The history of the school was also preserved in various ways in the office block. The names of previous principals, head girls and head boys, as well as photos of various school sports teams were displayed in the school hall. The school also kept albums with class photographs for each year. Trophies won in various activities were proudly displayed in a cabinet in the foyer. Principal A admitted, however, that they did not really keep in touch with former learners:

It is difficult to keep tabs with all the learners who have been at the school since it is a big school. A few learners who have just moved to high school do come back when the school has sporting activities or other functions.

The above reveals that the principal of School A paid attention to what he regarded as important value systems, ethos, faith and beliefs, as these elements serve to develop a sense of identity and establish a core mission among stakeholders of the school (Nordengren 2013: 7).

\section{Spiritual Culture in School B}

The photograph in Figure 11 shows a former learner of School B addressing the Grade 7 learners during career day. 


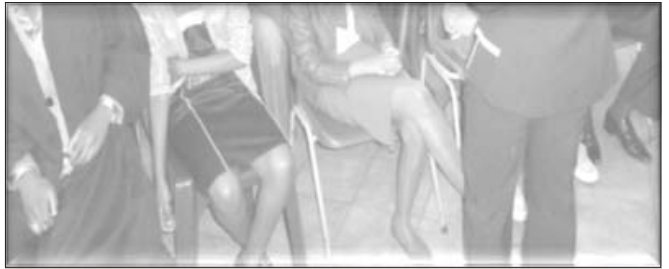

Fig. 11. Former learner addressing the Grade 7 learners

Source: Author

Unlike principal A, the principal of school B emphasised the need to keep in touch with former learners. According to Zhang (2008), former learners of a school are a practical expression of the institution's spiritual culture as they represent the alumni anecdotes of a school. Principal $B$ mentioned that the school benefits from making use of former learners in school projects as a way of getting the community involved.

Principal B also shaped his school's spiritual culture through sporting activities. Playing sport at school helps learners develop good sportsmanship as they are able to form positive relationships with their peers. Sport also provides learners with opportunities for social development. The principal made sure that sports fields of School B were taken good care of - they were well maintained and the grass was green even though it was shortly after winter. The playground area for the Foundation Phase was equally well maintained and had play equipment that was taken good care of and had just been painted.

Figure 12 shows School B celebrating Mandela Day. Principal B indicated that there was a need for teaching and learning not to occur in isolation, and he emphasised the need for education to integrate activities that happen outside the school walls - thereby creating opportunities for learning.

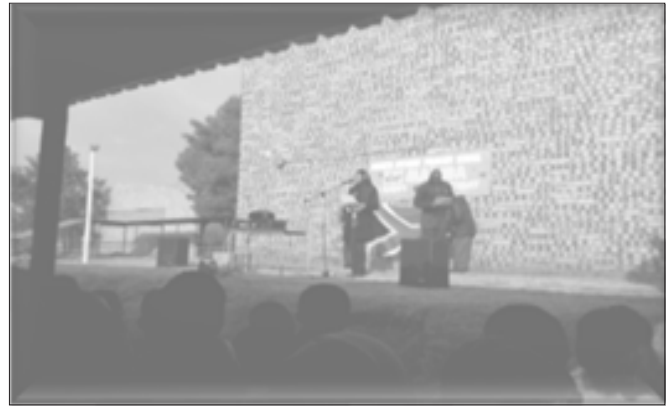

Fig. 12. Celebrating Mandela day

Source: Author
The literature review revealed that artefacts are observed in rituals and ceremonies (Tharp 2009: 2; Van Deventer and Kruger 2011: 20) where they demonstrate what is of importance and what is meaningful to the principal (Schein 2010: 23). Lunenburg (2011a: 5) acknowledges that most successful schools have people whom they recognise as their heroes. He adds that these heroes perpetuate the school's underlying values, as they become exemplars of what the school believes in and act as role models of what everyone should be striving for. These heroes are acknowledged by celebrating them and celebrations grow into memorable moments that occur in the school's daily life. Principal B regarded Nelson Mandela as a hero and consequently made Mandela Day an important day of celebration.

\section{Implications of the Findings}

The shaping of an effective school culture starts out from the visible (environmental culture) and then proceeds to the invisible (spiritual culture). However, the model described in Table 1 highlights the fact that it is the espoused values of the principals in effective schools allow their deep underlying assumptions to expand into positive actions that are firmly embedded in the visible artefacts of their schools. Parents and community members observe these actions and artefacts, and they flock to the school that seems to care for its learners and strives to prepare them for a life of success.

\section{CONCLUSION}

Considering the results of poor performing schools, principals who adapt to their bleak surroundings and create hope and shape a positive culture in their schools are truly inspirational. Only when principals recognise that staff members are the key to teaching and learning, that learners must be provided with the basic necessities, that communities need to embrace future generations, that collaboration helps to build an effective working environment, and that rituals and ceremonies need to be celebrated, can they adapt to the changing environment and make a positive change. The research in hand proves that the beams of hope in impoverished areas are principals who use their leadership skills well and who have the ability to handle complexity and adapt to constant change. 
Table 1: A model for shaping the culture in South African schools

\begin{tabular}{|c|c|c|}
\hline Espoused value & Deep underlying assumptions & Artefacts \\
\hline $\begin{array}{l}\text { Recognising that people } \\
\text { are the key to effective } \\
\text { teaching and learning }\end{array}$ & $\begin{array}{l}\text { Value the people and school } \\
\text { effectiveness and school } \\
\text { improvement will follow }\end{array}$ & $\begin{array}{l}\text { - Safety and security for teachers and } \\
\text { learners } \\
\text { - Tablets and maths and science improvement } \\
\text { - Lunch for teachers and secretaries }\end{array}$ \\
\hline $\begin{array}{l}\text { Recognising that learners } \\
\text { are deprived of the basic } \\
\text { necessities }\end{array}$ & $\begin{array}{l}\text { Basic needs of learners must be met } \\
\text { before effective learning can take } \\
\text { place }\end{array}$ & $\begin{array}{l}\text { - Blanket drive for learners } \\
\text { - Lunch for educators }\end{array}$ \\
\hline $\begin{array}{l}\text { Recognising that the commu- } \\
\text { nity needs to embrace the } \\
\text { education of the future } \\
\text { generation }\end{array}$ & $\begin{array}{l}\text { Schools are community development } \\
\text { centres }\end{array}$ & $\begin{array}{l}\text { - Career days with the community } \\
\text { - Involvement of parents during parent } \\
\text { evenings }\end{array}$ \\
\hline $\begin{array}{l}\text { Recognising the importance } \\
\text { of collaborating with people } \\
\text { to build up a working } \\
\text { environment }\end{array}$ & $\begin{array}{l}\text { Communication and collaboration } \\
\text { lead to school effectiveness }\end{array}$ & $\begin{array}{l}\text { - Communication with parents by means of } \\
\text { newsletters } \\
\text { - Code of conduct and vision constantly } \\
\text { communicated } \\
\text { - Resourceful - use economic ways of } \\
\text { building structures } \\
\text { - Role modelling - principal is a teacher }\end{array}$ \\
\hline $\begin{array}{l}\text { Recognising the importance } \\
\text { of having rituals and }\end{array}$ & $\begin{array}{l}\text { Appreciate the success of leaders } \\
\text { and follow their example }\end{array}$ & $\begin{array}{l}\text { - Celebrations of heroes } \\
\text { - Holding assemblies } \\
\text { - Inviting successful past learners to } \\
\text { motivate and inspire current learners }\end{array}$ \\
\hline $\begin{array}{l}\text { Adapting to a changing } \\
\text { environment }\end{array}$ & Team players and team leaders & $\begin{array}{l}\text { - Manage by walking around, through } \\
\text { physical presence } \\
\text { - Leaders need to be role models and "walk } \\
\text { the talk" and "talk the talk" }\end{array}$ \\
\hline
\end{tabular}

\section{RECOMMENDATIONS}

It is recommended that the DoE should hold workshops for principals to train them to adapt to changing conditions and be proactive in their school improvement strategies for shaping an effective school culture. Existing and prospective principals must be trained in basic leadership practices and be alerted to the four cultural dimensions identified by Zhang. Culture change progresses from the visible to the invisible. The deep underlying values of each principal predict his/her actions and the visible changes in their schools. Principals need to understand both their communities and the teachers with whom they work in order to shape a culture that will lead to effective teaching and learning. It is hoped that this study will draw wide interest and raise awareness among practitioners and policy makers regarding the importance of shaping an effective school culture and implementing good leadership practices in primary schools - not only in South Africa, but also in primary schools all over the world where challenging circumstances such as overcrowding, social inequality and lack of resources are experienced.

\section{REFERENCES}

Alexander G 2011. Dealing with the complexities of integration in cultural diverse rural school communities in South Africa. The Online Journal of New Horizons in Education, 1(1): 10-22.

Bold C 2012. Using Narrative in Reseach. London: Sage.

Bush T 2011. Theories of Educational Leadership and Management. Los Angeles: Sage.

Cohen L, Manion L, Morrison K 2009. Research Methods in Education. New York: Routledge.

Cohen L, Manion L, Morrison K 2013. Research Methods in Education. New York: Routledge.

Collier J, Collier M 1986. Visual Anthropology. Albuquerque, NM: University of New Mexico Press.

Cresswell J 2012. Qualitative Inquiry and Research Design: Choosing Among Five Approaches. Los Angeles: Sage.

Cresswell J 2012. Educational Research: Planning, Conducting and Evaluating Quantitative and Qualitative Research. Boston: Pearson.

Department of Education 2014. Government Gazzette: The South African Standards for Principalship. Enhancing the Image and Competency of School Principals. Pretoria: Department of Basic Education.

Department of Education 2013. Report on the Annual National Assessments. Pretoria: Department of Basic Education.

Eberlein E, Zhichao W 2014. Principals' understanding of their role in establishing a positive and enabling school. Mediterranean Journal of Social Sciences, 5(27): 1178-1186. 
Engels G, Hotton G, Devos G, Bouckenooghe D, Aelterman A 2008. Principals in schools with a positive school culture. Educational Studies, 34(3): 157-172.

Guthrie JW, Schuermann PJ 2011. Components of high perfoming school culture. In: J Guthrie (Ed.): Leading Schools to Success: Constructing and Sustaining High-Performing Schools. Thousand Oaks: Sage, pp. 39-72.

Heystek J, Niemann R, Van Rooyen J, Mosoge J, Bipath K 2012. People Leadership in Education. Johannesburg: Heinemann Publishers (Pty) Ltd.

Josselson R 2010. Narrative research. In: N Salkind (Ed.): Encyclopedia of Research Design. Thousand Oaks: Sage, pp. 869-875.

Kruger AG, Steinmann CF 2010. The organisational climate and culture of schools. In: I van Deventer, AG Kruger (Eds.): An Educator's Guide to School Management Skills. Pretoria: Van Schaik, pp.14-25.

Kuratani L, Lai E 2011. TEAM Lab - Photovoice Literature Review. From <http://teamlab.usc.edu/ training/archived-webinars.html $>$ (Retrieved on 25 March 2016).

Lapenta F 2011. Some theoretical and methodological views on photo-elicitation. In: E Margolis, L Pauwels (Eds.): The Sage Handbook of Visual Research Methods. London: Sage, pp. 201-214.

Leo U, Wickenberg P 2013. Professional norms in school leadership: Change efforts in implementation of education for sustainable development. Journal of Educational Change, 14(4): 403-422.

Lunenburg FC 2011a. Organizational culture-performance relationships: Views of excellence and theory Z. National Forum of Educational Administration Journal, 29(4): 1-10.

Lunenburg FC 2011b. Understanding organizational culture: A key leadership asset. National Forum of Educational Administration and Supervision Journal, 29(4): 1-12.

Modisaotsile B 2012. The falling standards of basic education. African Institute of South Africa, AISA Policy Brief, 72: 1-18.

Negis-Isik A, Gursel M 2013. Organisational culture in a successful primary school: An ethnographic study. Educational Studies: Theory and Practice, 13(1): 201-228.

November I, Alexander G, van Wyk MM 2010. Do principal-educators have the ability to transform schools? Teaching and Teacher Education, 26: 786-795.
Nzimande ED 1993. An Investigation into Why Some Black Parents Send Their Children to Multi-Racial Schools. Durban: University of Zululand.

Pauwels L 2011. An integrated conceptual framework for visual social research. In: E Margolis, L Pauwels (Eds.): The Sage Handbook of Visual Reasearch Methods. London: Sage, pp. 3-24.

Peterson KD, Deal P 2011. Shaping the School Culture. San Francisco: Jossey Bass.

Reeves D 2007. How do you change your school culture? Educational Leadership, 1: 94-96.

Richard HB, Catano N 2008. Qualities of Effective Principals. Alexandria, Virginia: Association for Supervision \& Curriculum Development (ASCD); ProQuest ebrary. Web. 29 March 2015.

Schein E 2010. Organisational Culture and Leadership. San Francisco: Jossey Bass.

Sorenson RD, Goldsmith LM 2009. The Principal's Guide to Managing School Personnel. California: Cornwin Press.

Spaull N 2013. Poverty and privilege: Primary school inequality in South Africa. International Journal of Education, 33: 437-447.

Tharp B 2009. Defining "Culture" and "Organizational Culture": From Anthropology to the Office. London: Harworth.

Turan S, Bektas F 2013. The relationship between school culture and leadership practices. Egitum Arastimalari-Eurasian Journal of Education Research, 52: 15

Van Deventer, I Kruger AG (Eds.) 2011. An Educator's Guide to School Management Skills. Pretoria: Van Schaik.

Zengele VT 2013a. Learner management. In: N Botha (Ed.): The Effective Management of a School: Towards Quality Outcomes. Pretoria: Van Schaik, pp. 179-192.

Zengele VT 2013b. The school as an organisation. In: N Botha (Ed.): The Effective Management of a School: Towards Quality Outcomes. Pretoria: Van Schaik, pp. 17-28.

Zhang J 2008. Four Cultures that Affect Schools' Improvement, Enhancement and Development. China: Wide Angle, Educational Development and Research.

Paper received for publiction on April 2016

Paper accepted for publication on August 2016 